\title{
Bone development during GH and GnRH analog treatment
}

\author{
Franco Antoniazzi, Giorgio Zamboni, Francesco Bertoldo ${ }^{1}$, Silvana Lauriola and Luciano Tatò \\ Pediatric Clinic and ${ }^{1}$ Department of Internal Medicine, University of Verona, Verona, Italy \\ (Correspondence should be addressed to Franco Antoniazzi, Clinica Pediatrica-Università di Verona, Policlinico 'Giambattista Rossi', Piazza Ludovico \\ Antonio Scuro, 10, I-37134 Verona, Italy; Email: franco.antoniazzi@univr.it)
}

\begin{abstract}
Estrogens, GH and IGFs are essential in the development and growth of the skeleton and for the maintenance of bone mass and density. Treatment of precocious puberty with GnRH analogs (GnRHa), by reducing sex steroid levels, leads to a situation of hypoestrogenism that may theoretically have a detrimental effect on bone mass during pubertal development. A reduction in bone mineral density (BMD) during GnRHa treatment has been demonstrated, but GnRHa treatment in patients with central precocious puberty (CPP) does not seem to impair the achievement of normal peak bone mass (PBM) at final height. However, calcium supplementation is effective in improving bone densitometric levels and may promote better PBM achievement. In children and adolescents with GH deficiency (GHD), BMD assessed by dual-energy X-ray absorptiometry (DEXA) and bone turnover are significantly reduced, but they are stimulated by GH treatment. GH treatment leads to improved bone density, function of the dose and duration of treatment, and patients may require prolonged GH treatment beyond the time of growth to improve PBM. After the discontinuation of GH therapy, the more active population had higher bone mineral content (BMC) levels than patients with low physical activity. In our experience, the therapeutic association of $\mathrm{GH}$ and calcium also represents a valuable tool in pursuing a proper BMC in GHD patients. We concluded that nonhormonal factors, such as physical activity and nutritional factors, are important in determining bone metabolism and bone mass.
\end{abstract}

European Journal of Endocrinology 151 S47-S54

\section{Introduction}

Normal bone mineral accretion during childhood and adolescence is a complex process involving genetic determinants, growth hormone $(\mathrm{GH})$ /insulin-like growth factor (IGF)-I effects, gonadal steroids, and nutritional and other environmental factors, such as physical activity (1). In healthy subjects, bone mass increases throughout childhood, with maximal bone mass accrual occurring in early to middle puberty and slowing in late puberty, reaching peak bone mass (PBM), defined as maximal bone mineral density (BMD) (2). About half of the adult PBM is accumulated during the adolescent growth spurt $(3-4)$. The precise age at which PBM is reached is both method- and site-dependent. Most of the lumbar and femoral BMD is achieved around 14.5-16.0 years in girls and 16.5-18.0 years in boys (5-8). Lumbar BMD continues to increase after the completion of growth, achieving PBM $1-2$ years later $(4,9)$. The magnitude of PBM achieved depends not only on genetic potential (race, sex and heredity) (10), but also on nutritional factors (calcium intake) $(11,12)$, disorders in timing of puberty (3), hormonal deficiency or pharmacologic treatments, and environmental factors as well as physical activity $(13,14)$.

Estrogens play an important role in skeletal maturation and mineralization and in the relevant increases in bone mass observed during puberty (15). Even at low levels, they promote normal skeletal growth and bone maturation in boys as well as girls, increasing and maintaining BMD (16), and controlling bone turnover rate (17). Hypoestrogenic conditions, such as natural menopause and GnRH analogs (GnRHa) administration in premenopausal women $(18,19)$, are characterized by bone mass reduction. Patients with aromatase deficiency or estrogen-receptor defects have a phenotype that includes tall stature and normal secondary sexual characteristics. These patients have osteoporosis and skeletal immaturity in adulthood despite normal androgen levels (20), with a dramatic improvement in bone density and completion of skeletal maturation after estrogen treatment (21).

GH and IGF are essential in the development and growth of the skeleton and for the maintenance of bone mass and density (22). Levels of GH and IGF-I increase dramatically during normal puberty, augmented by increasing levels of sex steroids. Much of the GH action on bone is mediated through IGF-I, which acts in an endocrine and autocrine/paracrine manner as a bone-trophic hormone that positively affects bone growth and bone turnover by stimulating osteoblasts, collagen synthesis and longitudinal bone growth (23).

In this review we will discuss particularly bone development in two situations: central precocious puberty (CPP) treated by GnRHa and GH deficiency (GHD) in children and adolescents before, during and after $\mathrm{GH}$ treatment. 


\section{Central precocious puberty (CPP)}

The spinal BMD of patients with untreated precocious puberty has been reported to be high for chronologic age (CA) (24) but appropriate for advanced bone age (BA) (25-27), or, in one study, to be lower than the normal mean for BA (28), probably because bone maturation and bone mineralization do not necessarily advance simultaneously (29).

Treatment of precocious puberty with GnRHa, by suppressing gonadotropin secretion and reducing sex steroid levels, leads to hypoestrogenism, which may be accompanied by delayed skeletal maturation and deficient bone mineralization $(25,26)$. This estrogen deprivation may theoretically have a detrimental effect on bone mass during pubertal development.

\section{CPP during treatment with GnRHa}

To test this hypothesis, we studied some years ago (26) bone mineral metabolism and mineralization by dualenergy X-ray absorptiometry (DEXA) before and during treatment in 10 girls aged 6.9-8.4 years affected by CPP and treated with GnRHa, in order to clarify the consequences of estrogen deficiency and of the reduction of GH-IGF-I axis activity.

During treatment, a decrease of serum estradiol levels from pubertal to prepubertal levels was observed. The GH peak following clonidine significantly diminished after 1 year. IGF-I and insulin-like growth factor-binding protein (IGFBP)-3 decreased, though not significantly. Osteocalcin levels, at pubertal range before therapy, decreased to prepubertal levels after 9 and 12 months of treatment, consistently with the arrest of pubertal development, when growth slowed following therapy (30). Urinary hydroxyproline, a marker of bone resorption, significantly decreased after 12 months. Before therapy, lumbar spine and radius bone mass were high for $\mathrm{CA}$, but appropriate for BA; after 12 months of treatment, bone mass in the lumbar spine, but not in the radius, decreased significantly. These changes in bone density may indicate that the initial event, as a consequence of treatment of $\mathrm{CPP}$, is a suppression of bone formation. In our patients, GnRHa administration negatively affected both cortical and trabecular bone, in accordance with another report (25). Cortical bone is less sensitive to rapid changes in bone metabolism, and the rate of bone loss is much lower than that of trabecular bone. The bone loss measured by lateral DEXA, excluding from analysis the posterior portions of the vertebrae (mainly cortical bone), was, in fact, twofold higher than in anteroposterior (AP) scans. When DEXA is used in growing children, an increase of bone size alone induces an increase in photon absorption. When corrected for the volume (vBMD), bone mass significantly decreased. The decline in estrogen levels is associated with increased turnover and bone loss in adult women, but, in the present study, bone turnover diminished. The bone loss we observed can be explained only by an uncoupling between bone resorption and bone formation. Reduced bone formation is the primary consequence of GnRHa therapy, and this could possibly be related to decreased GH secretion. After the initial reduction of bone formation, there could be, after a few months, a comparable decrease in bone resorption, with consequent transient bone loss.

A reduction in BMD during GnRHa treatment has been demonstrated in other studies (25), although in one study BMD values increased, and the BMD S.D. score for age and skeletal age did not change during treatment (27). It is obvious that, at such a critical age, a decrease in BMD, instead of an increase as expected in normal growing girls, might have a negative impact on PBM and produce a higher risk of postmenopausal osteoporosis. At that time, we stated that this reduction is possibly entirely reversible, as proven in premenopausal women treated with GnRHa (18).

\section{CPP at the end of GnRHa treatment}

In a previous study on girls affected by CPP, we demonstrated that BMD reduction during GnRHa therapy was reversible and preventable by providing calcium supplementation from the beginning of treatment (31).

To determine whether GnRHa treatment impaired the achievement of an adequate bone mass at growth completion and whether calcium supplementation improved bone mass in patients treated with GnRHa, we conducted a longitudinal study (32) to evaluate bone mass after long-term GnRHa therapy with or without calcium supplementation in females affected by CPP who had reached final height. In fact, it was demonstrated that calcium intake correlates with bone density in healthy children and adolescents (33), and that calcium supplementation above the recommended dietary allowances increases bone density in children (34).

We studied 48 Caucasian females affected by CPP (age at diagnosis, 7.19 \pm 0.96 years), randomly assigned to two groups: group A $(n=21)$ treated with GnRHa and group B $(n=27)$ treated with GnRHa plus calcium gluconolactate and carbonate ( $1 \mathrm{~g}$ calcium/day in two doses) for at least 2 years. Auxologic parameters (standing height, weight, body mass index) and BMD at the lumbar spine (L2-L4, anteroposterior (AP)-BMD; lateral BMD; and volumetric (vBMD)), total BMC (TBMC) and total BMD (TBMD), by DEXA were evaluated at the beginning, at the end of treatment and at final height.

The vBMD was significantly higher in group B than in group $A$ at the end of the treatment period and at final evaluation $(P<0.05)$. The percent change $(\Delta \%)$ between the start and end of treatment period in AP$\mathrm{BMD}$ and $\mathrm{vBMD}$ was significantly higher in group $\mathrm{B}$ 
than in group A and also between the start of treatment and final evaluation (Table 1).

In all our females with CPP (both groups A and B) at final evaluation, treated with GnRHa, bone densitometric parameters (final TBMC, TBMD, AP-BMD L2$\mathrm{L} 4$ and $\mathrm{vBMD}$ ) were in the normal range for age and sex, even if lower than in controls, but the differences were not statistically significant (Fig. 1). Therefore, in our study, as in other studies (35-38), GnRHa treatment in patients with CPP does not seem to impair the achievement of normal PBM. In calcium-supplemented patients, vBMD levels at the end of therapy and final evaluation were significantly higher than in patients treated only with GnRHa. Moreover, $\Delta \%$ AP$\mathrm{BMD}$ and $\Delta \%$ vBMD between the beginning of treatment and final evaluation were also significantly higher in calcium-supplemented patients than in patients treated only with GnRHa, with a significant relationship with the duration of calcium supplementation. Thus, calcium supplementation is effective in improving bone densitometric levels and may preserve better PBM achievement (32).

A limitation of the study is that, as well known, PBM is not achieved at final height but later in life (2). Therefore, the effect of precocious puberty and its treatment on PBM should be re-evaluated later, at approximately 20-30 years of age.

Probably the majority of the general population do not require calcium supplementation because of good genetic background, adequate diet, and good physical activity. But in some individuals, such as patients treated with drugs that potentially interfere with bone mineral metabolism, it is probably better to increase calcium intake (2).

\section{GnRHa treatment outside CPP}

In a randomized clinical trial, treatment with GnRH agonist was used to increase adult height in adolescents with short stature and normally timed puberty (39). In this study, the principal adverse event in the GnRH-agonist group was reduced lumbosacral BMD during treatment and inadequate catch-up accretion of bone mineral after treatment (mean lumbar vertebral BMD at the time adult height was achieved, 1.6 \pm 1.2 S.D. below population mean, vs $0.3 \pm 1.2$ S.D. below population mean in the placebo group; $P<0.001)$. Due to this adverse effect, the authors stated that such treatment cannot be routinely recommended to augment height in adolescents with normally timed puberty.

\section{GH deficiency (GHD)}

In children and adolescents with GHD, BMD assessed by DEXA and bone turnover are significantly reduced (40), reflecting decreased bone modeling and remodeling (41), because of delayed bone maturation or absence of $\mathrm{GH}$ anabolic activity (42).

Reduced BMD detected by DEXA is commonly reported in untreated adult patients with childhood $(43,44)$ or adult onset GHD $(45-46)$ (the former showing more pronounced effects of GHD on bone mass than the latter), with respect to normal controls and treated patients, and one-third of patients had lumbar bone density 2 S.D. or more below the normal mean (48).

Reduced BMD by DEXA in GHD adults may be explained either by a failure to achieve normal PBM or by subsequent bone loss during adult life $(45,46)$, and the severity of bone loss is proportional to the biochemical severity of GHD (49).

However, DEXA provides an areal density measurement rather than a true volumetric density, and low bone density measurements may reflect reduced height and thus bone size in these patients. When bone density is measured by peripheral quantitative computed tomography (pQCT) or estimated by calculated methods from DEXA measurements to correct for bone size (vBMD), spinal bone density is still reported as reduced if compared with age- and sex-matched reference data $(50,51)$. However, in recent studies,

Table 1 Chronologic age $(C A)$ and bone age (BA) of patients at various times of evaluation: densitometric values (volumetric bone mineral density-vBMD), $\Delta \%$ AP-BMD and $\Delta \%$ vBMD between the start and end of treatment (start-stop), end of treatment and final evaluation (stop-final), and the start of treatment and final evaluation (start-final).

\begin{tabular}{|c|c|c|c|c|}
\hline & & Start of treatment & End of treatment & Final evaluation \\
\hline $\mathrm{CA}$ & & $7.3 \pm 0.9$ & $11.3 \pm 0.97$ & $16.2 \pm 1.9$ \\
\hline $\mathrm{BA}$ & & $8.80 \pm 1.24$ & $12.35 \pm 0.43$ & $16.93 \pm 0.98^{\star}$ \\
\hline \multirow[t]{3}{*}{ vBMD $\mathrm{g} / \mathrm{cm}^{3}$} & group $A$ & $0.175 \pm 0.016$ & $0.192 \pm 0.021$ & $0.227 \pm 0.024$ \\
\hline & group $B$ & $0.177 \pm 0.014$ & $0.213 \pm 0.022^{\mathrm{a}}$ & $0.246 \pm 0.023^{\mathrm{b}}$ \\
\hline & & Start-end of treatment & End of treatment-final evaluation & Start of treatment-final evaluation \\
\hline \multirow[t]{2}{*}{$\Delta \%$ AP-BMD } & group A & $16.16 \pm 1.90$ & $40.81 \pm 2.45$ & $56.97 \pm 1.45$ \\
\hline & group B & $20.36 \pm 1.10^{\mathrm{a}}$ & $40.87 \pm 3.32$ & $61.23 \pm 1.61^{a}$ \\
\hline \multirow[t]{2}{*}{$\Delta \%$ vBMD } & group $\mathrm{A}$ & $9.26 \pm 5.15$ & $17.18 \pm 3.05$ & $28.01 \pm 5.76$ \\
\hline & group B & $19.08 \pm 3.52^{\mathrm{a}}$ & $14.81 \pm 3.08$ & $36.69 \pm 5.01^{\mathrm{a}}$ \\
\hline
\end{tabular}

* In each case $>15$ years.

${ }^{a} P<0.01$ vs group $A$.

${ }^{\mathrm{b}} P<0.05$ vs group $\mathrm{A}$. 


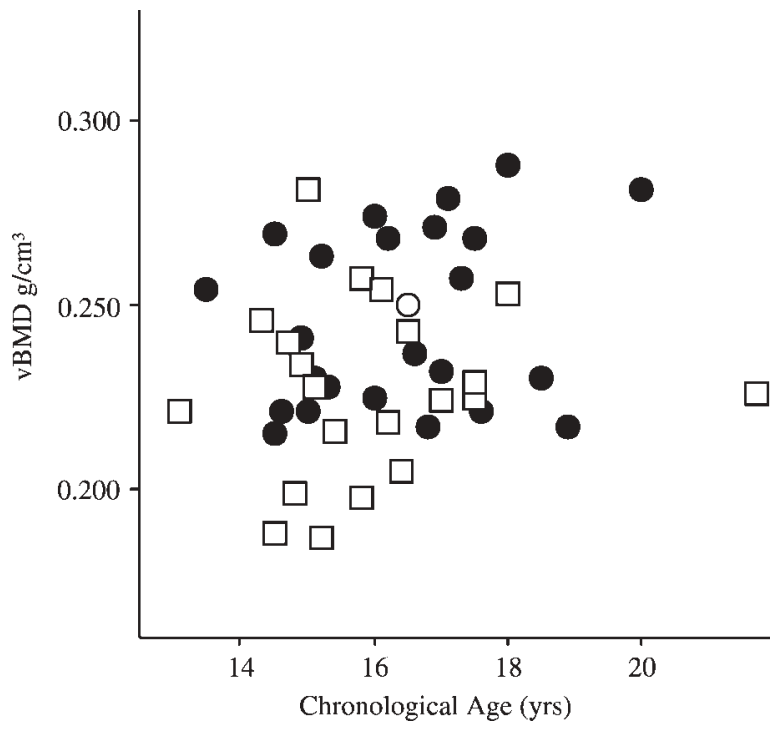

Figure 1 Central precocious puberty (CPP). Individual vBMD levels at final evaluation in group $\mathrm{A}$ ( $\mathrm{GnRHa}$ alone, white squares) and group $\mathrm{B}$ (GnRHa and $\mathrm{Ca}$, black circles). vBMD levels were significantly higher in group $\mathrm{B}$ than in group $\mathrm{A}(P<0.05)$

pQCT showed that cortical bone density was not reduced in GHD children (52), and vBMD was reported as normal to near normal (mean Z scores: $-1.2,+0.8$, and +0.8 for lumbar spine, femoral neck and total skeleton respectively) in patients with genetic growth hormone-releasing hormone (GHRH)-receptor deficiency (53). These reports stressed that GH/IGF-I deficiency has relatively little impact on bone mineralization during the bone accretion phase, in marked contrast to its effect on bone elongation and overall bone size.

Adult-onset GHD patients have a threefold increase in fracture risk compared with the general population (54), and it was recently demonstrated that children with GHD had an approximately fourfold decreased fracture frequency from diagnosis up to final height compared with controls (61).

\section{GH treatment}

GH treatment in GHD children stimulates bone turnover (40-42) and improves BMD $(42,55-58)$.

In treated GHD children, an increase in lumbar bone density by DEXA after 6 months of treatment, but no significant change in calculated vBMD until after 2 years of treatment, was reported. Early changes in bone density measurements may reflect changes in bone size, but prolonged treatment results in improvement in net bone formation (42). Longitudinal data in GHD children treated for an average of 4 years demonstrated a significant improvement in radial and lumbar bone density. The greatest improvement was observed with the longest treatment duration, with z-scores approaching mean reference values (58).
At final height, normal $(60,61)$ or reduced (62) mean values of lumbar BMD were found in GH-treated GHD patients. Approximately 20\% of GHD children treated with $\mathrm{GH}$ had a value of lumbar BMD between -1 and -2 S.D. of the normal mean at final height, with increased susceptibility to fractures during $\mathrm{GH}$ treatment (61). Reduced lumbar BMD was found expecially in patients with GHD who had received interrupted and low-dose $\mathrm{GH}$ treatment during the period of pituitary-derived $\mathrm{GH}$ during childhood $(44,59)$, but it has been shown that there was no difference in lumbar BMD at final height between patients with GHD who had received standard $(0.3 \mathrm{mg} / \mathrm{kg}$ per week $)$ or high GH dosage $(0.7 \mathrm{mg} / \mathrm{kg}$ per week) (62).

In patients with GHD, increased lumbar BMD after the attainment of final height has been found 2 years (60) after discontinuation of $\mathrm{GH}$ treatment. GH-retreated patients with childhood $(63,64)$ or adult $(65)$ onset GHD also had an increased BMD after discontinuation of GH treatment that could be due to a persisting effect of $\mathrm{GH}$ treatment inducing a bone-remodeling cycle, which continues until the new bone is fully mineralized (65).

In adolescents with GHD who normally discontinue $\mathrm{GH}$ at completion of linear growth, BMD is substantially lower than PBM for a young adult population. A recent report on adolescents with GHD who continued GH administration after the completion of linear growth showed an increased lumbar BMD after 12 months of therapy, which was not observed in untreated patients (66). Moreover, reinstitution of GH replacement after final height in severely GH-deficient patients induced significant progression toward PBM $(67,68)$.

All these data suggest that $\mathrm{GH}$ treatment leads to improved bone density, according to the dose and duration of treatment, and that patients may require prolonged GH treatment beyond the time of growth to improve PBM. Cessation of $\mathrm{GH}$ at achievement of final height, by limiting PBM, may predispose to clinically significant osteoporosis in later life, also by a superimposed accelerated loss of BMD with advancing age similar to the situation observed in adult-onset GHD.

Pubertal GH-deficient patients treated with GH and GnRHa had a significantly lower BMC after 3 years of therapy. This difference, however, did not persist after both groups of patients reached final height.

\section{GH treatment and calcium supplementation}

We conducted a preliminary study to evaluate BMD during GH therapy, with or without calcium supplementation, to determine whether calcium supplementation improved bone mass in patients treated with GH and calcium.

Twelve prepubertal Caucasian GH-deficient patients (seven females, five males), 5-14 years old, took part in the study. The diagnosis of GHD was based on the 
following criteria: height of $\leq 2$ SDS; bone age delay of $>2$ years compared with $\mathrm{CA}$; peak $\mathrm{GH}$ of $<10 \mathrm{ng} / \mathrm{ml}$ in at least two consecutive pharmacologic tests; reduced IGF-I. None of the patients had organic GHD or multiple pituitary hormone deficiency, all being affected by idiopathic isolated GHD, as assessed by full endocrine evaluation and pituitary molecular resonance imagery (MRI).

Patients, all treated with $\mathrm{GH}$ at a dose of $0.033 \mathrm{mg} / \mathrm{kg}$ per day 6 days a week, were randomly assigned to two groups (A and B) comparable for age, BA weight and height, using a computer pseudo-random number generator. Patients in group A $(n=6)$ were treated solely with $\mathrm{GH}$; patients in group B $(n=6)$ received GH plus supplementation of calcium gluconolactate and carbonate $(1 \mathrm{~g}$ calcium/day per os in two doses).

No patients received other drugs known to interfere with bone mineral metabolism. All the subjects were instructed to continue their usual physical activity and diet, thereby ensuring adequate caloric (70$80 \mathrm{cal} / \mathrm{kg}$ per day), protein $(>1 \mathrm{~g} / \mathrm{kg}$ per day), calcium ( $>800 \mathrm{mg} /$ day), and phosphate $(>800 \mathrm{mg} /$ day) intake during treatment. Diet and dietary calcium intake were investigated by a weighed food record and exercise by an exercise diary. Compliance with assumption of calcium supplementation was checked by a diary.

At the start of therapy, the patients of groups A and B were comparable for age, weight, height and body composition, BMC and bone turnover. The biochemical data of bone turnover of patients of groups A and B after 12 months of treatment evidenced comparable values in both groups. After 12 months of therapy, BMC significantly increased in patients of group B, supplemented with calcium, compared with those of group A treated solely with $\mathrm{GH}(P<0.05)$.

Therefore, in our experience, the therapeutic association of $\mathrm{GH}$ and calcium represents a valuable tool in pursuing not only the final target but also proper BMC in GHD patients.

\section{Physical activity at the end of GH treatment}

For better determination of body composition after discontinuation of GH therapy, we re-evaluated 20 young men with GHD diagnosed in childhood that had completed pubertal development (age 18-20 years), 12 months after stopping therapy for at least 6 years with $\mathrm{GH}$ at the dose of $0.6 \mathrm{IU} / \mathrm{kg}$ per week. The parameters studied included final height, spontaneous nocturnal GH secretion and body composition by DEXA (Expert XL; Lunar Corp., Madison, WI, USA), which enabled assessment of whole-body as well as regional soft tissue composition. Re-evaluation of $\mathrm{GH}$ secretion in these patients showed that 12 remained GH deficient (persistent GHD) with abnormal spontaneous nocturnal GR secretion (11 multiple pituitary deficiency and one isolated GHD), while eight recovered normal somatotropic secretion (transient GHD). BMC was positively influenced, as expected, by GR action. GHD patients, 12 months after discontinuation of GH therapy, had BMC levels very close to the control group of normal young adults. One year after stopping the GH treatment, patients with confirmed GHD showed an increased fat mass as compared with the value at the end of the treatment; in this group, we divided patients into two distinct populations, on the basis of exercise quantity. The more active population had higher BMD levels, expecially at lumbar and thoracic spine than the patients with low physical activity (Table 2) (69). We concluded that nonhormonal factors, such as physical activity and nutritional factors, are important in determining bone metabolism and bone mass.

\section{Conclusions}

Normal bone mineral accretion during childhood and adolescence is a complex process involving genetic determinants, GH/IGF-I effects, gonadal steroids, and nutritional and other environmental factors, such as physical activity. Estrogens, GR and IGFs are essential in the development and growth of the skeleton and for the maintenance of bone mass and density.

Treatment of precocious puberty with GnRHa, by suppressing gonadotropin secretion and reducing sex steroid levels, leads to a situation of hypoestrogenism, which may theoretically have a detrimental effect on bone mass during pubertal development. A reduction in BMD during GnRHa treatment has been demonstrated, but GnRHa treatment in patients with CPP does not seem to impair the achievement of a normal PBM at final height. However, calcium supplementation is effective in improving bone densitometric levels and may promote better PBM achievement.

In children and adolescents with GH deficiency, BMD by DEXA and bone turnover are significantly reduced, but are stimulated by GH treatment. At final height, normal or reduced mean values of lumbar BMD were found in GH-treated GHD patients. GH treatment leads to improved bone density, function of the dose

Table 2 Bone mineral density $\left(\mathrm{g} / \mathrm{cm}^{2}\right)$ in GHD patients 12 months after discontinuation of GH therapy, subdivided by physical activity (high and low).

\begin{tabular}{lcc}
\hline & High & Low \\
\hline Number & 7 & 5 \\
Subtotal & $1.082 \pm 0.043$ & $0.870 \pm 0.037$ \\
Lumber spine & $1.187 \pm 0.073$ & $0.742 \pm 0.069$ \\
Thoracic spine & $1.004 \pm 0.039$ & $0.649 \pm 0.042$ \\
Left leg & $1.288 \pm 0.086$ & $1.056 \pm 0.065$ \\
Right leg & $1.273 \pm 0.084$ & $1.043 \pm 0.038$ \\
Left arm & $0.787 \pm 0.024$ & $0.673 \pm 0.033$ \\
Right arm & $0.802 \pm 0.022$ & $0.675 \pm 0.036$ \\
\hline
\end{tabular}


and duration of treatment, and patients may require prolonged GH treatment beyond the time of growth to improve PBM. After the discontinuation of GH therapy, the more active population had higher BMC levels than patients with low physical activity. In our experience, the therapeutic association of GH and calcium also represents a valuable tool in promoting proper BMC in GHD patients.

We concluded that nonhormonal factors, such as physical activity and nutritional factors, are important in determining bone metabolism and bone mass.

\section{References}

1 Soyka LA, Fairfield WP \& Klibanski A. Clinical Review 117. Hormonal determinants and disorders of peak bone mass in children. Journal of Clinical Endocrinology and Metabolism $2000 \mathbf{8 5}$ 3951-3962.

2 Heaney RP, Abrams S, Dawson-Hughes B, Looker A, Marcus R, Matkovic $\mathrm{V} \&$ Weaver $\mathrm{C}$. Peak bone mass. Osteoporosis International 200011 985-1009.

3 Parfitt AM. The two faces of growth: benefits and risks to bone integrity. Osteoporosis International $19944382-398$.

4 Matkovic V, Jelic T, Wardlaw GM, Ilich JZ, Goel PK, Wright JK, Andon MB, Smith KT \& Heaney RP. Timing of peak bone mass in Caucasian females and its implication for the prevention of osteoporosis. Inference from a cross-sectional model. Journal of Clinical Investigation 199493 799-808.

5 Bonjour J, Theintz G, Buchs B, Slosman D \& Rizzoli R. Critical years and stages of puberty for spinal and femoral bone mass accumulation during adolescence. Journal of Clinical Endocrinology and Metabolism 199173 555-563.

6 Theintz G, Buchs B, Rizzoli R, Slosman D, Clavien H, Sizonenko PC \& Bonjour JP. Longitudinal monitoring of bone mass accumulation in healthy adolescent girls: evidence for marked reduction after 16 years of age at the levels of lumbar spine and femoral neck in female subjects. Journal of Clinical Endocrinology and Metabolism 199275 1060-1065.

7 Lu PW, Cowell CT, Lloyd-Jones SA, Briody JN \& Howman-Giles R. Volumetric bone mineral density in normal subjects, aged 5-27 years. Journal of Clinical Endocrinology and Metabolism $1996 \mathbf{8 1}$ 1586-1590.

8 Boot AM, de Ridder MA, Pols HA, Krenning EP \& de Muinck KeizerSchrama SM. Bone mineral density in children and adolescents: relation to puberty, calcium intake, and physical activity. Journal of Clinical Endocrinology and Metabolism 199782 57-62.

9 Fournier PE, Rizzoli R, Slosman DO, Theintz G \& Bonjour JP. Asynchrony between the rates of standing height gain and bone mass accumulation during puberty. Osteoporosis International $19977525-532$.

10 Krall EA \& Dawson-Hughes B. Heritable and life-style determinants of bone mineral density. Journal of Bone and Mineral Research $199381-9$.

11 Johnston CC Jr, Miller JZ, Slemenda CW, Reister TK, Hui S, Christian JC \& Peacock M. Calcium supplementation and increases in bone mineral density in children. New England Journal of Medicine $199232782-87$.

12 Barr SI, Petit MA, Vigna YM \& Prior JC. Eating attitudes and habitual calcium intake in peripubertal girls are associated with initial bone mineral content and its change over 2 years. Journal of Bone and Mineral Research 200116 940-947.

13 Schonau E, Werhahn E, Schiedermaier U, Mokow E, Schiessl H, Scheidhauer K \& Michalk D. Influence of muscle strength on bone strength during childhood and adolescence. Hormone Research 199645 (Suppl 1) 63-66.

14 Bass S, Pearce G, Bradney M, Hendrich E, Delmas PD, Harding A \& Seeman E. Exercise before puberty may confer residual benefits in bone density in adulthood: studies in active prepubertal and retired female gymnasts. Journal of Bone and Mineral Research $199813500-507$.

15 Gislanz V, Roe TF, Mora S, Costin G \& Goodman WG. Changes in vertebral bone density in black girls and white girls during childhood and puberty. New England Journal of Medicine 1991325 1597-1600.

16 Klein KO, Martha PM Jr, Blizzard RM, Herbst T \& Rogol AD. A longitudinal assessment of hormonal and physical alterations during normal puberty in boys. II. Estrogen levels as determined by an ultrasensitive bioassay. Journal of Clinical Endocrinology and Metabolism 199681 3203-3207.

17 Riggs BL, Khosla S \& Melton LJ III. Sex steroids and the construction and conservation of the adult skeleton. Endocrine Reviews 200223 279-302.

18 Matta WH, Shaw RW, Hesp R \& Evans R. Reversible trabecular bone density loss following induced hypoestrogenism with the GnRH analogue Buserelin in premenopausal women. Clinical Endocrinology 198829 45-51.

19 Scharla SH, Minne HW, Waibel-Treber S, Schaible A, Lempert UG, Wuster C, Leyendecker G \& Ziegler R. Bone mass reduction after estrogen deprivation by long-acting gonadotropin-releasing hormone agonist and its relation to pretreatment serum concentrations of 1,25-dihydroxyvitamin D3. Journal of Clinical Endocrinology and Metabolism 199070 1055-1061.

20 Smith EP, Boyd J, Frank GR, Takahashi H, Cohen RM, Specker B, Williams TC, Lubahn DB \& Korach KS. Estrogen resistance caused by a mutation in the estrogen-receptor gene in a man. New England Journal of Medicine 1994331 1056-1061.

21 Bilezikian JP, Morishima A, Bell J \& Grumbach MM. Increased bone mass as a result of estrogen therapy in a man with aromatase deficiency. New England Journal of Medicine 1998339 599-603.

22 Carrel AL \& Allen DB. Effects of growth hormone on body composition and bone metabolism. Endocrine 2000 12 163-172.

23 LeRoith D \& Butler AA. Insulin-like growth factors in pediatric health and disease. Journal of Clinical Endocrinology and Metabolism $1999844355-4360$.

24 Takahashi Y, Minamitani K, Kobayashi Y, Minagawa M, Yasuda T \& Niimi H. Spinal and femoral bone mass accumulation during normal adolescence: comparison with female patients with sexual precocity and with hypogonadism. Journal of Clinical Endocrinology and Metabolism $1996 \mathbf{8 1} 1248-1253$.

25 Saggese G, Bertelloni S, Baroncelli GI, Battini R \& Franchi G. Reduction of bone density: an effect of gonadotropin releasing hormone analogue treatment in central precocious puberty. European Journal of Pediatrics 1993152 717-720.

26 Antoniazzi F, Bertoldo F, Zamboni G, Valentini R, Sirpresi S, Cavallo L, Adami S \& Tatò L. Bone mineral metabolism in girls with precocious puberty during gonadotropin releasing hormone agonist treatment. European Journal of Endocrinology $1995133412-417$.

27 Neely EK, Bachrach LK. Hintz RL, Habiby RL, Slemenda CW, Feezle $\mathrm{L} \&$ Pescovitz $\mathrm{OH}$. Bone mineral density during treatment of central precocious puberty. Journal of Pediatrics $1995127819-822$.

28 Arisaka O, Nakayama Y, Tokita A \& Yabuta K. Bone mineralization and bone maturation in precocious puberty. Archives of Pediatric and Adolescent Medicine 1997151 101-102.

29 Partsch CJ, Heger S \& Sippell WG. Management and outcome of central precocious puberty. Clinical Endocrinology $200256129-148$.

30 Antoniazzi F, Bertoldo F, Lauriola S, Sirpresi S, Gasperi E, Zamboni G \& Tatò L. Prevention of bone demineralization by calcium supplementation in precocious puberty during gonadotropin-releasing hormone agonist treatment. Journal of Clinical Endocrinology and Metabolism $1999841992-1996$.

31 Antoniazzi F, Zamboni G, Bertoldo F, Lauriola S, Mengarda F, Pietrobelli A \& Tatò L. Bone mass at final height in precocious puberty after gonadotropin-releasing hormone agonist with and without calcium supplementation. Journal of Clinical Endocrinology and Metabolism $2003 \mathbf{8 8} 1096-1101$.

32 Ruiz JC, Mandel C \& Garabedian M. Influence of spontaneous calcium intake and physical exercise on the vertebral and femoral 
bone mineral density of children and adolescents. Journal of Bone and Mineral Research 199510 675-682.

33 Bonjour JP, Carrie AL, Ferrari S, Clavien H, Slosman D, Theintz G \& Rizzoli R. Calcium-enriched foods and bone mass growth in prepubertal girls: a randomized, double-blind, placebo-controlled trial. Journal of Clinical Investigation 199799 1287-1294.

34 Heger S, Partsch CJ \& Sippell WG. Long-term outcome after depot gonadotropin-releasing hormone agonist treatment of central precocious puberty: final height, body proportions, body composition, bone mineral density, and reproductive function. Journal of Clinical Endocrinology and Metabolism $1999 \mathbf{8 4} 4583-4590$.

35 Bertelloni S, Baroncelli GI, Sorrentino MC, Perri G \& Saggese G. Effect of central precocious puberty and gonadotropin-releasing hormone analogue treatment on peak bone mass and final height in females. European Journal of Pediatrics $1998 \mathbf{1 5 7}$ 363-367.

36 Van der Sluis IM, Boot AM, Krenning EP, Drop SL \& de Muinck Keizer-Schrama SM. Longitudinal follow-up of bone density and body composition in children with precocious or early puberty before, during and after cessation of GnRH agonist therapy. Journal of Clinical Endocrinology and Metabolism 200287 506-512.

37 Kapteijns-van Kordelaar S, Noordam K, Otten B \& van den Bergh J. Quantitative calcaneal ultrasound parameters and bone mineral density at final height in girls treated with depot gonadotrophinreleasing hormone agonist for central precocious puberty or idiopathic short stature. European Journal of Pediatrics $2003 \mathbf{1 6 2}$ 776-780.

38 Yanovski JA, Rose SR, Municchi G, Pescovitz OH, Hill SC, Cassorla FG \& Cutler GB Jr. Treatment with a luteinizing hormone-releasing hormone agonist in adolescents with short stature. New England Journal of Medicine 2003348 908-917.

39 Cowell CT, Woodhead H \& Brody J. Bone markers and bone mineral density during growth hormone treatment in children with growth hormone deficiency. Hormone Research 200054 (Suppl 1) $44-51$.

40 Baroncelli GI, Bertelloni S, Ceccarelli C, Cupelli D \& Saggese G. Dynamics of bone turnover in children with GH deficiency treated with GH until final height. European Journal of Endocrinology 2000 $142549-556$.

41 Van der Sluis IM, Boot AM, Hop WC, de Rijke YB, Krenning EP \& de Muinck Keizer-Schrama SM. Long-term effects of growth hormone therapy on bone mineral density, body composition, and serum lipid levels in growth hormone deficient children: a 6year follow-up study. Hormone Research 200258 207-214.

42 Hyer SL, Rodin DA, Tobias JH, Leiper A \& Nussey SS. Growth hormone deficiency during puberty reduces adult bone mineral density. Archives of Disease in Childhood $1992671472-1474$.

43 Kaufman J, Taelman P, Vermeulen A \& Vandeweghe M. Bone mineral status in growth hormone deficient males with isolated and multiple pituitary deficiencies of childhood onset. Journal of Clinical Endocrinology and Metabolism 1992 74 118-123.

44 Carroll PV, Christ ER, Bengtsson BA, Carlsson L, Christiansen JS, Clemmons D, Hintz R, Ho K, Laron Z, Sizonenko P, Sonksen PH, Tanaka T \& Thorne M. Growth hormone deficiency in adulthood and the effects of growth hormone replacement: a review. Journal of Clinical Endocrinology and Metabolism $1998 \mathbf{8 3} 382-395$.

45 Monson JP, Drake WM, Carroll PV, Weaver JU, Rodriguez-Arnao J \& Savage MO. Influence of growth hormone on accretion of bone mass. Hormone Research 200258 (Suppl 1) 52-56.

46 Johannsson G \& Bengtsson BA. Growth hormone and the acquisition of bone mass. Hormone Research 199748 (Suppl 5) 72-77.

47 De Boer H, Blok GJ, Van Lingen A, Teule GJJ. Lips P \& Van Der Veen EA. Consequences of childhood-onset growth hormone deficiency for adult bone mass. Journal of Bone and Mineral Research 19949 1319-1325.

48 Colao A, Di Somma C, Pivonello R, Loche S, Aimaretti G, Cerbone G, Faggiano A, Corneli G, Ghigo E \& Lombardi G. Bone loss is correlated to the severity of growth hormone deficiency in adult patients with hypopituitarism. Journal of Clinical Endocrinology and Metabolism 199984 1919-1924.
49 O'Halloran DJ, Tsatsoulis A, Whitehouse RW, Holmes SJ, Adams JE \& Shalet SM. Increased bone density after recombinant human growth hormone $(\mathrm{GH})$ therapy in adults with isolated $\mathrm{GH}$ deficiency. Journal of Clinical Endocrinology and Metabolism 1993 76 1344-1348.

50 Baroncelli GI, Bertelloni S, Ceccarelli C \& Saggese G. Measurement of volumetric bone mineral density accurately determines degree of lumbar undermineralization in children with growth hormone deficiency. Journal of Clinical Endocrinology and Metabolism 199883 3150-3154.

51 Schweizer R, Martin DD, Schwarze CP, Binder G, Georgiadou A, Ihle J \& Ranke MB. Cortical bone density is normal in prepubertal children with growth hormone $(\mathrm{GH})$ deficiency, but initially decreases during $\mathrm{GH}$ replacement due to early bone remodeling. Journal of Clinical Endocrinology and Metabolism $2003 \mathbf{8 8}$ 5266-5272.

52 Maheshwari HG, Bouillon R, Nijs J, Oganov VS, Bakulin AV \& Baumann G. The impact of congenital, severe, untreated growth hormone $(\mathrm{GH})$ deficiency on bone size and density in young adults: insights from genetic GH-releasing hormone receptor deficiency. Journal of Clinical Endocrinology and Metabolism $2003882614-2618$.

53 Wuster C, Abs R, Bengtsson BA, Bennmarker H, Feldt-Rasmussen U, Hernberg-Stahl E, Monson JP, Westberg B \& Wilton P. KIMS Study Group and the KIMS International Board. Pharmacia \& Upjohn International Metabolic Database. The influence of growth hormone deficiency, growth hormone replacement therapy, and other aspects of hypopituitarism on fracture rate and bone mineral density. Journal of Bone and Mineral Research $200116398-405$.

54 Zamboni G, Antoniazzi F, Radetti G, Musumeci C \& Tatò L. Effects of two different regimens of recombinant human growth hormone therapy on bone mineral density of patients with growth hormone deficiency. Journal of Pediatrics $1991119483-485$.

55 Saggese G, Baroncelli GI, Bertelloni S, Cinquanta L \& Di Nero G. Effects of long-term treatment with growth hormone on bone and mineral metabolism in children with growth hormone deficiency. Journal of Pediatrics $199312237-45$.

56 Stamoyannou L, Karachaliou F, Gioureli E, Voskaki E, Mengreli C, Bartsocas CS \& Koutselinis A. Effect of growth hormone therapy on bone metabolism of growth hormone deficient children. European Journal of Pediatrics $1997156592-596$.

57 Kandemir N, Gonc EN \& Yordam N. Responses of bone turnover markers and bone mineral density to growth hormone therapy in children with isolated growth hormone deficiency and multiple pituitary hormone deficiencies. Journal of Pediatric Endocrinology and Metabolism 200215 809-816.

58 Saggese G, Baroncelli GI, Bertelloni S \& Barsanti S. The effect of long-term growth hormone $(\mathrm{GH})$ treatment on bone mineral density in children with GH deficiency. Role of GH in the attainment of peak bone mass. Journal of Clinical Endocrinology and Metabolism $1996813077-3083$.

59 Fors H, Bjarnason R, Wirent L, Albertsson-Wikland K, Bosaeust L, Bengtsson BA \& Johannsson G. Currently used growth-promoting treatment of children results in normal bone mass and density. A prospective trial of discontinuing growth hormone treatment in adolescents. Clinical Endocrinology 200155 617-624.

60 Baroncelli GI, Bertelloni S, Sodini F \& Saggese G. Lumbar bone mineral density at final height and prevalence of fractures in treated children with growth hormone deficiency. Journal of Clinical Endocrinology and Metabolism 200287 3624-3631.

61 Mauras N, Attie KM, Reiter EO, Saenger P \& Baptista J. The Genentech, Inc., Cooperative Study Group. High dose recombinant human growth hormone $(\mathrm{GH})$ treatment of $\mathrm{GH}$-deficient patients in puberty increases near-final height: a randomized, multicenter trial. Journal of Clinical Endocrinology and Metabolism 200085 3653-3660.

62 Benbassat CA, Wasserman M \& Laron Z. Changes in bone mineral density after discontinuation and early reinstitution of growth 
hormone (GH) in patients with childhood-onset GH deficiency. Growth Hormone IGF Research 19999 290-295.

63 Holmes SJ, Whitehouse RW, Economou G, O'Halloran DJ, Adams JE \& Shalet SM. Further increase in forearm cortical bone mineral content after discontinuation of growth hormone replacement. Clinical Endocrinology 199542 3-7.

64 Biller BMK, Sesmilo G, Baum HBA, Hayden D, Schoenfeld D \& Klibanski A. Withdrawal of long-term physiological growth hormone $(\mathrm{GH})$ administration: differential effects on bone density and body composition in men with adult-onset GH deficiency. Journal of Clinical Endocrinology and Metabolism $2000 \mathbf{8 5}$ 970-976.

65 Drake WM, Carroll PV, Maher KT, Metcalfe KA, Camacho-Hübner C, Shaw NJ, Dunger DB, Cheetham TD, Savage MO \& Monson JP. The effect of cessation of growth hormone (GH) therapy on bone mineral accretion in $\mathrm{GH}$-deficient adolescents at the completion of linear growth. Journal of Clinical Endocrinology and Metabolism $2003 \mathbf{8 8} 1658-1663$.

66 Ter Maaten JC, De Boer H, Kamp O, Stuurman L \& Van Der Veen EA. Long-term effects of growth hormone $(\mathrm{GH})$ replacement in men with childhood-onset GH deficiency. Journal of Clinical Endocrinology and Metabolism $1999842373-2380$.

67 Shalet SM, Shavrikova E, Cromer M, Child CJ, Keller E, Zapletalova J. Moshang T, Blum WF, Chipman JJ, Quigley CA \& Attanasio AF. Effect of growth hormone (GH) treatment on bone in postpubertal GH-deficient patients: a 2-year randomized, controlled, dose-ranging study. Journal of Clinical Endocrinology and Metabolism 2003 $\mathbf{8 8} 4124-4129$.

68 Mericq V, Gajardo H, Eggers M, Avila A \& Cassorla F. Effects of treatment with GH alone or in combination with LHRH analog on bone mineral density in pubertal GH-deficient patients. Journal of Clinical Endocrinology and Metabolism 2002 87 84-89.

69 Antoniazzi F, Zamboni G, Radetti G, Mengarda F, Lauriola S, Serra A \& Tatò L. Growth hormone deficiency. Treatment with growth hormone and body composition. Archives de Pediatrie 19985 (Suppl 4) $327 \mathrm{~S}-331 \mathrm{~S}$.

Received 26 February 2004

Accepted 17 May 2004 